\title{
Perceived Rate Of Returns To Education: A UAE Perspective
}

Jaya Abraham, Abu Dhabi University, UAE Shilpa Iyanna, Abu Dhabi University, UAE Makhtar Sarr, Abu Dhabi University, UAE

\begin{abstract}
The measurement of rate of returns is central to the profitability analysis of educational investments. Literature suggests that the ex-ante approach of measuring the perceptions of the beneficiaries is a reliable indicator of returns to education. The present study estimates the perceived rate of returns to higher education for undergraduate students in UAE. Respondents were asked to provide estimates of future expected earnings with and without higher education. The study indicates that the Emiratis and non-Emirati students differ significantly in the estimates of perceived rate of returns. The findings of this study offer strategic insights on the economic considerations in the higher education enrollment process in the UAE. It also emphasizes the need for better counseling among the Emirati school students regarding the importance of higher education and return to higher education.
\end{abstract}

Keywords: Higher Education; Perceptions; Perceived Rate Of Returns; Emirati; UAE

\section{INTRODUCTION}

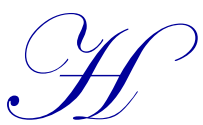

uman capital is considered an important determinant of economic growth and plays a crucial role in promoting poverty alleviation and economic growth. When a country invests in its human capital through education, it has the potential for generating benefits to the society that goes beyond those acquired by the individuals involved. Most developing countries, including those in the MENA (Middle East and North Africa) region, have committed substantial resources over the last 40 years to expand and improve their education systems (worldbank.org). According to the most recent statistics released by the World Bank, the world average, in relation to education investment, is $14.2 \%$. Government spending on the educational sector in the MENA region, however, is $18.6 \%$ (Khaleej Times, $27^{\text {th }}$ Jan, 2013).

Investing in its human capital through education has always been a strategic priority for the UAE (United Arab Emirates). As President His Highness Sheikh Zayed Bin Sultan Al Nahyan, founder of the UAE, noted, "The greatest use that can be made of wealth is to invest it in creating generations of educated and trained people." In 1975, the rate of adult literacy was 54 percent among men and 31 percent among women. Today, literacy rates for both genders are nearly 90 percent. Education expenditure in the UAE now accounts for 25 percent of the total federal budget, underlining the critical importance of education in the social and economic development agenda of the government (uae-embassy.org).

A number of factors are used to measure a country's effort to increase the level of human capital through education, including public spending, enrollment rates, and the number of years of schooling. Table 1 provides a brief overview for a few randomly selected countries in the MENA region for the above-mentioned factors. 
Table 1: Factors Used To Measure A Country's Effort To Increase The Level Of Human Capital Through Education

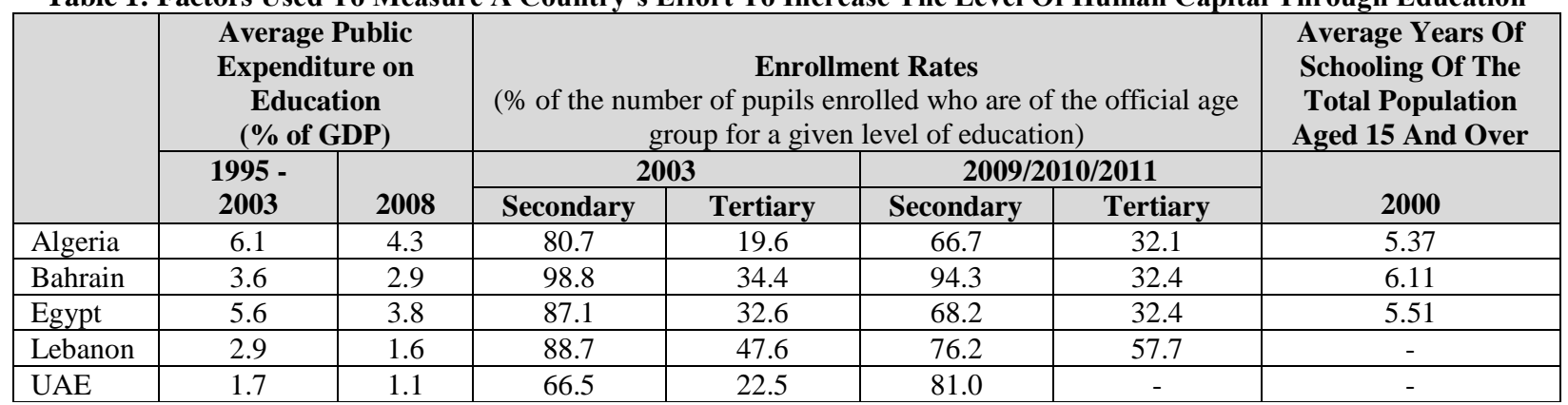

Source: UNESCO Institute for Statistics through World Bank EdStats Data (accessed February, 2013)

\section{Rate of Returns to Education}

Investment in education calls for a need to examine the rate of returns. Several genres of concepts have been developed in the literature in response to methodological and contextual issues in the analysis of returns to education. Among them, the most popular concepts are private returns, social returns, and public returns. The private returns to education explain the demand for higher education among students. It measures the costs and benefits realized by individual students. The social rate of returns measures the costs and benefits to the society based on productivity differentials and therefore cover the actual costs of education whether paid from the pockets of the students or not. This rate of returns is aimed to assess the benefits of public spending in higher education. The public rate of returns to education is a narrower form of social returns as it considers the extra taxes and social security benefits contributed by the university graduates (Psacharopoulos, 2009).

Social returns, on the other hand, are based on the costs and benefits of education as they are realized by the state or society as a whole. The costs are all inclusive; i.e., they refer to what education really costs rather than just what the students pay out of pocket. Social rates of returns should be based on productivity differentials rather than earnings. Therefore, the social returns to education are used to assess the efficiency of public spending on education (Psacharopoulos, 2009). However, social returns are not useful in analysing demand for higher education.

Since the 1960's, a multitude of studies have been made in different parts of the world to estimate the rate of returns to higher education (HE). These estimates, in general, depend on statistical data from government agencies or data provided by other authors (Psacharopoulos, 1973, 1985, 1994; Psacharopoulos and Patrinos, 2004). Such rates are based on ex-post analysis and do not necessarily reflect the perceptions of the higher education aspirants (Menon, 2008).

Several studies in the 1990's suggest a measure that considers the perceptions of the actual beneficiaries of higher education; i.e., the students, are a far more reliable indicator of returns to education without the limitation associated with the use of secondary data. Such rates are based on ex-ante analysis and therefore are more realistic and reflect the trend in the labor market (Hung, Chung \& Ho, 2000; Menon, 1997; Psacharopoulos and Sanyal, 1981).

Further, perceived rate of returns estimates support the human capital theory explanation for demand for higher education. An increase in perceived rate of returns to higher education makes prospective students increase their demand for higher education. However, the actual enrolment decision may be influenced by many factors other than the returns to education. The students may be forced to change their original intentions, subject to any constraints such as entry restrictions or the cost of education (Menon, 2008).

Studies that measure the perceived rate of returns to higher education in the Middle East, in general, and the UAE, in particular, are scant. The present study is an attempt to fill this research gap. Thus, the objectives of this study are:

- $\quad$ to estimate the perceived rate of returns for undergraduate business students in the United Arab Emirates

- $\quad$ to compare the perceived rate of returns between Emirati and non-Emirati students 


\section{Computation Of Rate Of Returns}

The rate of returns to any investment is the discount rate which equates the stream of benefits to the stream of costs and is relevant in education as it involves investments in human capital. Historically, rate of returns to higher education was calculated as the earnings differential between the university and secondary school graduates (Psacharopoulos, 1973). Included are the direct costs of education and the opportunity costs (measured as the earnings that the secondary school graduates sacrifice to pursue undergraduate degree). However, this method assumed an earnings stream of 45 years from the age of 15 to 60 years. Therefore, the method has restricted use because it includes earnings discounted over a very long time period. The simpler method, called the short cut method (Psacharopoulos, 1992), is based on the net earning differential at graduation and thus can be used without considering the age of the respondents. measured as:

Using the short cut method, the perceived rate of returns from undergraduate business degree can be

$\mathrm{R}=\left(\mathrm{E}_{\mathrm{h}}-\mathrm{E}_{\mathrm{s}}\right) / \mathrm{N}\left(\mathrm{E}_{\mathrm{s}}+\mathrm{C}_{\mathrm{h}}\right)$

where $E_{h} \& E_{s}$ are the annual mean earnings of the students with undergraduate and secondary education, $C_{h}$ is the direct cost of education, and $\mathrm{N}$ is the number of years of educational investment. Therefore, this method does not consider the concave nature of the age-earning profiles and gives more weight to the earnings in the early years of work.

\section{DATA}

Primary data were collected using questionnaires distributed to 101 students in the final year of the undergraduate business program. The students from the final year were chosen for the study because their perceptions about the earnings from work were expected to be more realistic. Respondents were asked to record their perceptions of future earnings at two points in time (at the start of work and ten years later), with and without an undergraduate degree. Also, information on variables such as age, nationality, and socio-economic status were collected.

The sample included 47 Emirati and 54 non-Emirati undergraduate business students. Details of the sample are presented in Table 2.

Table 2: Sample Distribution Based On Gender And Nationality

\begin{tabular}{|l|c|c|c|}
\hline \multicolumn{1}{|c|}{ Sample Details } & Male & Female & Total \\
\hline Emirati & 26 & 21 & 47 \\
\hline Non-Emirati & 33 & 21 & \\
\hline Total & 59 & 42 & 101 \\
\hline
\end{tabular}

The annual earnings for each student were worked out as follows: The differences between the estimated monthly earnings were computed and averaged over the number of years. The monthly estimates were then multiplied by a factor of 12 (for the number of months in a year) to convert them to total annual earnings. The same procedure was followed to estimate the annual earnings ten years after the students joined the workforce. Using this procedure, the earning streams for the students in the two contexts; namely, with and without higher education, were worked out.

When a student chooses to enter higher education after school-level education, he foregoes the earnings of the four years that he spends in college. This is the opportunity cost of choosing higher education. In addition to this, the direct costs of undergraduate business education (Iyanna and Abraham, 2012) were included in the stream of costs. 


\section{RESULTS AND DISCUSSION}

Table 3.

The perceived average salary was calculated for the Emirati students in the sample and is presented in

Table 3: Perceived Average Monthly Salary For The Emirati Undergraduate Business Students

\begin{tabular}{|l|c|c|}
\hline \multirow{2}{*}{ Career Point } & \multicolumn{2}{|c|}{ Expected Average Monthly Salary (AED/Month) } \\
\cline { 2 - 3 } & Without $\boldsymbol{H E}$ & With $\boldsymbol{H E}$ \\
\hline Initial year $\left(\mathrm{Y}_{0}\right)$ & 10638.89 & 16611.11 \\
\hline After10years $\left(\mathrm{Y}_{10}\right)$ & 16111.11 & 26666.67 \\
\hline
\end{tabular}

With secondary school-level education, an Emirati youth expects to get a monthly salary of AED 10638.89. If he starts his career with an undergraduate degree, the perceived average monthly salary will be $56.14 \%$ more. With ten years of work experience, the perceived salary will be $65 \%$ higher than the one without a degree.

The perceived average salary for the non-Emirati students in the sample is presented in Table 4.

Table 4: Perceived Average Monthly Salary For The Non-Emirati Undergraduate Business Students

\begin{tabular}{|l|c|c|}
\hline \multirow{2}{*}{ Career Point } & Expected Average Monthly Salary (AED/Month) \\
\cline { 2 - 3 } & Without HE & With HE \\
\hline Initial year $\left(\mathrm{Y}_{0}\right)$ & 5380.43 & 8456.52 \\
\hline After10years $\left(\mathrm{Y}_{10}\right)$ & 11217.39 & 22228.26 \\
\hline
\end{tabular}

With secondary school education, the non-Emirati student expects to get a salary of AED5380.43 in the initial year. If he starts his career with an undergraduate degree, the perceived monthly salary will be $57.17 \%$ higher; i.e., AED 8456.52. With ten years of experience, the perceived salary, with an undergraduate degree, will be AED 22228.26 , which is $98.16 \%$ higher than the salary perception of secondary school leavers.

The perceived rate of returns includes not just the expected average monthly returns but the direct cost of education, as well as the opportunity costs of favoring higher education. Table 5 describes the perceived rate of returns estimated for the sample.

Table 5: Perceived Rate Of Returns In 2011/12 Calculated Using Short Cut Method

\begin{tabular}{|l|c|c|cc|}
\hline \multicolumn{1}{|c|}{ Sample Data } & N & Mean (\%) & SD \\
\hline Emirati & 47 & 5.82 & 5.07 \\
\hline Non-Emirati & 54 & 8.63 & 5.88 \\
\hline All students & 101 & 7.13 & 5.67 \\
\hline
\end{tabular}

The returns estimated indicate that the students are aware of the income differential in favor of undergraduate education. The rate of returns for the non-Emirati students was much higher (8.63\%) as compared to returns for the Emirati students (5.82\%). This implies that there is significant difference between the Emirati and non-Emirati students' perceptions toward the returns from an undergraduate degree.

\section{IMPLICATIONS AND FUTURE RESEARCH}

The data indicate that according to the perception of Emirati youth, it is profitable to enter the workforce immediately after secondary school (see Table 2). Further, considering the direct costs and the opportunity cost of pursuing undergraduate education, the perceived value of returns to higher education is lower for Emirati students as opposed to non-Emiratis (see Table 4). Reports suggest that the students get lucrative job offers as soon as they finish Grade 10 and therefore are not interested in collegiate education (The National, May 16, 2011). Findings from the study support this statement. However, in the long run, this could reduce the quality of human capital as, indeed, the central thesis of human capital theory is that education improves quality of human resources.

Several studies suggest that the low perceived rate of returns from higher education occur in an environment where there is imperfect information on part of the decision-makers in education; namely, the students 
(Smith and Powell, 1990; Betts, 1996). Interestingly, literature associates the imperfect information on the rate of returns with low income countries. The findings from the study defy this logic as UAE is ranked as a high income economy (Forbes, 2012).

In this scenario, raising the legal age to join the workforce could compel the Emirati youth to pursue higher education. The school career guidance services should highlight the long-run benefits of higher education to students and their parents. Building a strong system of incentives into the undergraduate education plan for the Emiratis could also encourage them to pursue higher education.

Policy makers need to track possible changes in perceptions of Emirati youth toward earnings of not only those who pursue higher education but also those who join the labor force immediately after completion of school. If the perceived costs are higher than the perceived benefits, demand for higher education may decline. Therefore, the perceived returns to education can act as an indicator of demand for education at any point in time.

The findings presented in this study highlight the perceived rate of returns to education and its influence on the educational decisions made by young Emiratis. However, this should not lead one to lose sight of the several other variables that have a significant effect on the decision to enter higher education. Further analysis, including the other relevant variables, will lead to more informed understanding of the enrolment in undergraduate programs. Another area worthy of future research is the comparison of perceived rate of returns with social rate of returns, if reliable data on costs and earnings are available. Also, a longitudinal study could help in understanding the change in perceived returns to education over time.

\section{AUTHOR INFORMATION}

Dr. Jaya Abraham is a Visiting Assistant Professor at Abu Dhabi University. Dr. Jaya's research interests include developmental economics, economic efficiency of small firms, higher education, marketing decision behavior and services marketing. E-mail: jaya.abraham@adu.ac.ae (Corresponding author)

Dr. Shilpa Iyanna is Assistant Professor of Marketing at Abu Dhabi University. Shilpa's research interests are in the area of customer behavior which interconnects with various other streams of research, mainly customer value, value co-creation, S-D logic, consumer attitudes and behavior and other related areas. E-mail: shilpa.iyanna@adu.ac.ae

Dr. Makhtar Sarr is an Assistant Professor of Mathematics and Statistics at The Abu Dhabi University. Dr. Sarr's research interests lie mainly in the fields of Nonparametric Statistics and Applied Mathematics. Dr. Sarr is also doing some collaborative work in the areas of Statistical Modelling by Wavelets and Neural Networks. E-mail: makhtar.sarr@adu.ac.ae

\section{REFERENCES}

1. Betts, Julian (1996). What do students know about wages? Evidence from a survey of Undergraduates, Journal of Human Resources, 31(1), p. 27-56.

2. Hung, F.Chung, Y.,\&Ho, E.S. (2000). To work or to continue education? The choice of senior secondary students in Shenzhen,China, Higher Education, 39 , 455-467.

3. Iyanna, S., \& Abraham, J. A. (2012). A comparative cost analysis of undergraduate business degrees for international students in selected countries, International Journal of Business and Management, 7(4), 145153.

4. Menon, M. (1997). Perceived rate of returns to higher education in Cyprus", Economics of Education Review, $16,425-430$.

5. Menon, M. (2008). Perceived rates of returns to higher education:Further evidence from Cyprus, Economics of Education Review, 27 , 39-47.

6. Olaniyan, D. A. and Okemakinde, T. (2008). Human capital theory: Implications for educational development, Pakistan Journal of Social Science, 5(5): 479 - 483.

7. Psacharopoulos, G. (1973). Returns to education:An international Comparison. Amsterdam: Elsevier. 
8. Psacharopoulos, G. \& Sanyal, B. (1981). Student expectations and labour market performance: The case of Philippines. Higher Education, 10 , 449-472.

9. Psacharopoulos, G. (1985). Returns to education: A further international update and implications. Journal of Human Resources, 20, 583-604.

10. Psacharopoulos, G. (1992). Rate of return studies. In B. Clark \& G. Neave (Eds.), The Encyclopedia of Higher Education (pp.999-1003), Oxford: Pergamon Press.

11. Psacharopoulos, G. (1994). Returns to investment in education: A global update. World Development,22 , 1325-1343.

12. Psacharopoulos, G., \& M. Woodhall (1997). Education for development: An analysis of investment choice, New York Oxford University Press.

13. Psacharopoulos,G., and Patrinos, H. (2004). Returns to investment in education: A further update. Education Economics, 12 . 112-134.

14. Psacharopoulos, G. (2009), Returns to investment in higher education - A European survey, A contribution to the higher education funding reform project, CHEPS-led consortium for the European Commission.

15. Sakamota, A. and P. A. Powers (1995) Education and the dual labor market for Japanese men in America, Social Review, 60(2): $222-246$.

16. Schultz, T. W. (1971), Investment in Human Capita, The Free Press, New York.

17. Smith, Herbert L., \& Brian Powell (1990). Great Expectations: Variations in income expectations among college seniors, Sociology of Education, 63(3), p. 194-207.

18. http://www.khaleejtimes.com/nation/inside.asp?section=educationnation \&xfile=/data/educationnation/2013 /january/educationnation january $25 . \mathrm{xml}$

19. www.forbes.com

20. www.thenational.ae/news/uae-news/school-leaving-age-will-be-raised-to-16

21. www.uae-embassy.org

22. www.worldbank.org 